\title{
Betaglycan Gene (TGFBR3) Polymorphism Is Associated with Increased Risk of Endometrial Cancer
}

\author{
Piotr K. Zakrzewski ${ }^{1, *(D)}$, Ewa Forma ${ }^{1}$, Adam I. Cygankiewicz ${ }^{1}{ }^{1}$, Magdalena Bryś ${ }^{1}(\mathbb{D}$, \\ Katarzyna Wójcik-Krowiranda ${ }^{2}$, Andrzej Bieńkiewicz ${ }^{2}$, Andrzej Semczuk ${ }^{3}$ and \\ Wanda M. Krajewska ${ }^{1}$ (1) \\ 1 Department of Cytobiochemistry, Faculty of Biology and Environmental Protection, University of Lodz, \\ Pomorska 141/143, 90-236 Lodz, Poland; ewa.forma@biol.uni.lodz.pl (E.F.); \\ adam.cygankiewicz@biol.uni.lodz.pl (A.I.C.); magdalena.brys@biol.uni.lodz.pl (M.B.); \\ wanda.krajewska@biol.uni.lodz.pl (W.M.K.) \\ 2 Department of Gynecological Oncology, Medical University of Lodz, Pabianicka 62, 93-513 Lodz, Poland; \\ kkrowiranda@o2.pl (K.W.-K.); abienkiewicz@wp.pl (A.B.) \\ 3 IInd Department of Gynecology, Medical University of Lublin, Jaczewskiego 8, 20-090 Lublin, Poland; \\ andrzejsemczuk@umlub.pl \\ * Correspondence: piotr.zakrzewski@biol.uni.lodz.pl; Tel.: +48-42-635-52-99
}

Received: 29 July 2020; Accepted: 22 September 2020; Published: 24 September 2020

check for updates

\begin{abstract}
We investigated single nucleotide polymorphism (SNP) of the betaglycan gene (TGFBR3) encoding the TGF $\beta$ co-receptor in endometrial cancer (EC) and its association with betaglycan expression. The study group included 153 women diagnosed with EC and 248 cancer-free controls. SNP genotyping and gene expression were analyzed using TaqMan probes. Three out of the eight SNPs tested, i.e., $r s 12566180$ (CT; OR $=2.22 ; 95 \% \mathrm{CI}=1.15-4.30 ; p=0.0177$ ), $r s 6680463$ (GC; OR $=2.34 ; 95 \% \mathrm{CI}=1.20-4.53 ; p=0.0120$ ) and $r s 2296621$ (TT; OR $=6.40 ; 95 \%$ $\mathrm{CI}=1.18-34.84 ; p=0.0317)$ were found to be significantly associated with increased risk of EC (adjusted to age, body mass index, menarche and parity). Among the analyzed SNPs, only rs2296621 demonstrated the impact on the increased cancer aggressiveness evaluated by the WHO grading system (G3 vs. G1/2, GT-OR $=4.04 ; 95 \% \mathrm{CI}=1.56-10.51 ; p=0.0026 ; \mathrm{T}-\mathrm{OR}=2.38 ; 95 \% \mathrm{CI}=1.16-4.85$; $p=0.0151)$. Linkage disequilibrium (LD) analysis revealed high $\mathrm{LD}(\mathrm{r} 2 \geq 0.8)$ in two haploblocks, constructed by $r s 2770186 / r s 12141128$ and $r s 12566180 / r s 6680463$, respectively. In the case of C/C haplotype $(\mathrm{OR}=4.82 ; 95 \% \mathrm{CI}=1.54-15.07 ; p=0.0116$-Bonferroni corrected $)$ and $\mathrm{T} / \mathrm{G}$ haplotype $(\mathrm{OR}=3.25 ; 95 \% \mathrm{CI}=1.29-8.15 ; p=0.0328$-Bonferroni corrected $)$ in haploblock $r s 12566180 / r s 6680463$, significantly higher frequency was observed in patients with EC as compared to the control group. The genotype-phenotype studies showed that SNPs of the TGFBR3 gene associated with an increased risk of EC, i.e., $r s 12566180$ and $r s 2296621$ may affect betaglycan expression at the transcriptomic level ( $r s 12566180-\mathrm{CC}$ vs. TT, $p<0.01$; $r s 2296621-\mathrm{GG}$ vs. TT, $p<0.001$, GT vs. TT, $p<0.05$ ). Functional consequences of evaluated TGFBR3 gene SNPs were supported by RegulomeDB search. In conclusion, polymorphism of the TGFBR3 gene may be associated with an increased EC occurrence, as well as may be the molecular mechanism responsible for observed betaglycan down-regulation in EC patients.
\end{abstract}

Keywords: SNP; TGF $\beta$; TGFBR3; betaglycan; endometrial cancer

\section{Introduction}

Endometrial cancer (EC) is one of the leading female cancer-related causes of death with around 382,069 new cases and 89,929 deaths worldwide each year. Significantly higher incidence rate is observed in developed countries in contrast to less-developed ones with the world morbidity around 
8.4/100,000 of female population [1]. In Poland, its incidence rate takes the third position among cancers and occurs predominantly in women in their menopausal and post-menopausal age $(30.2 / 100,000)$. However, EC occurrence in Poland has risen rapidly in the last three decades, although the mortality trend is stable, as it is observed in global population [2]. In the future, the incidence of endometrial cancer is expected to increase due to the gradual aging of the population.

According to the clinico-pathological features and different pathogenesis, endometrial cancer is commonly classified into type I-endometrioid and type II-non-endometrioid. Type I is the most diagnosed type of endometrial cancer (75-90\%) and develops from glandular cells in the endometrium lining. Endometrioid tumors are represented predominantly by endometrial adenocarcinomas, which are estrogen-dependent and tend to be low grade with favorable prognosis. Non-endometrioid cancers typically include papillary serous or clear cell carcinomas, in general, histological subtypes characterized by more aggressive phenotypes with poor outcome [3,4]. Endometrial cancer is mostly diagnosed in the early stages (FIGO I and II) as it is observed in $75 \%$ of patients. In this stage, 5 -year overall survival is $74-91 \%$, whereas for more advanced stages, 5 -year overall survival rates are $57-66 \%$ and $20-26 \%$, for FIGO III and FIGO IV, respectively [5]. Molecular classification distinguished based on a large scale, comprehensive genetic analysis of EC according to The Cancer Genome Atlas includes four subgroups, i.e., DNA polymerase epsilon ultramutated (POLE), microsatellite instability hypermutated (MSI), copy-number low and copy-number high subgroup. Each of categories is characterized by distinct clinical, pathological and molecular alterations. The POLE subgroup displays polymerase epsilon mutations in exonuclease domain, which results in a remarkable high mutation rate $\left(232 \times 10^{-6}\right.$ mutations per $\left.\mathrm{Mb}\right)$. The MSI subgroup is related to deficiencies in a DNA mismatch repair system leading to common mutations of ARID5B, PTEN, PIK3CA and PIK3R1 genes. The copy-number low subgroup is described also as microsatellite stable and corresponds to more than half of low-grade endometrioid tumors, whereas copy-number high subgroup reflects to serous histopathology [6-8]. Moreover, up to $5 \%$ of ECs are described as familial ones, due to the loss-of-function or expression alterations of DNA mismatch repair genes, i.e., (MLH1, MSH2, MSH6 or PMS2). The most frequent form of inherited EC is associated with Lynch syndrome, which increases the risk of developing EC to $25-60 \%[9,10]$.

According to the molecular findings, impaired TGF $\beta$ signaling has been reported in ECs [11-13]. The canonical signal, mediated via TGF $\beta$ factors, occurs through TGF $\beta$ membrane receptors type I (TGF $\beta$ RI) and type II (TGF $\beta$ RII), which possess serine/threonine kinase activity. Among huge number of TGF $\beta$ factors, three classical TGF $\beta$ isoforms, i.e., TGF $\beta 1$, TGF $\beta 2$ and TGF $\beta 3$, were identified. Dimeric TGF $\beta$ factors bind to the TGF $\beta$ RII receptor, which in turn activates TGF $\beta$ RI receptor. The activated TGF $\beta$ RII/TGF $\beta$ RI complex trans-phosphorylates cytoplasmic effectors, i.e., Smad2/3 proteins, forming a heterocomplex with the Smad4 protein, are translocated to the nucleus, where together with other transcription factors, regulate gene expression [14]. Appropriate signaling in TGF $\beta$ pathway requires the presence of co-receptors termed TGF $\beta$ receptors type III (TGF $\beta$ RIII). TGF $\beta$ co-receptors are deprived of any known enzymatic activity; however, they are anchored in the cell membrane, and they are responsible for TGF $\beta$ ligand presentation to their canonical TGF $\beta$ receptors. The plethora of TGF $\beta$ ligands and receptors results in the regulation of many cellular processes, such as growth and proliferation, survival, apoptosis, cells adhesion, remodeling of extracellular matrix, angiogenesis and embryonic development [15].

The first identified TGF $\beta$ co-receptor was betaglycan [16]. Betaglycan gene (TGFBR3), located on chromosome 1, encodes a transmembrane proteoglycan. Literature data and our previous studies indicate the contribution of betaglycan loss to the development and progression of cancers originated from different tissue types, i.e., breast, endometrium, ovary, prostate, lung, bladder, liver, pancreas, kidney, and neuroblastoma [17-28]. Down-regulation of betaglycan expression seems to be engaged in the impaired TGF $\beta$ signaling initiated by the TGF $\beta 2$ isoform to which it displays the highest affinity.

Until now, there is no efficient and rapid molecular method suitable for neither early diagnosis nor prediction of EC risk. This became a basis for betaglycan (TGFBR3) gene single nucleotide 
polymorphism (SNP) investigations. In the current study, we examined eight SNPs within the TGFBR3 gene and their association with primary EC and their clinico-pathological variables, as well as potential impact on betaglycan expression.

\section{Materials and Methods}

\subsection{Study Population}

In the study, we enrolled only Caucasian women born and living in Poland. The case-control study involved 153 women who underwent surgery of EC and 248 healthy individuals which served as cancer-free controls. Biological material (cancer group-endometrial tissue samples and peripheral blood; cancer-free control-peripheral blood) was collected in the II ${ }^{\text {nd }}$ Department of Gynecology, Lublin Medical University, Lublin, Poland and in the Department of Gynecological Oncology, Medical University of Lodz, Lodz, Poland, between 2012-2017. Inclusion criteria for case group, included women with diagnosed primary endometrial adenocarcinomas, who had not received neither hormonal therapy, radiation therapy nor chemotherapy prior surgery; whereas control group was recruited from non-related women during periodic health check-ups, who have never been diagnosed with endometrial cancer or other tumors.

Cancer tissue specimens, after the surgery, were divided into two portions; one was fixed in buffered formalin ( $\mathrm{pH}$ 7.4) for routine histological assessment while the other was immediately placed at $-70^{\circ} \mathrm{C}$. Clinical stage was assigned based on surgico-pathological findings according to the revised FIGO staging, while WHO classification was applied to determine the histological type and grade. Table 1 presents socio-demographic and clinical characteristics of the patients and examined samples. All studied cancer samples were classified as endometrioid cancers (type I)—endometrial adenocarcinomas.

\subsection{Ethical Approval}

The study was conducted in accordance with the ethical principles of the 1975 Helsinki Declaration and its later amendments. The local Independent Committees of Bioethics of Lublin Medical University, Medical University of Lodz and University of Lodz approved the tissues collections and study protocols. All methods in the study were performed in accordance with above-mentioned bioethical permissions. All participating subject gave written, informed consent prior to enrolment.

\subsection{Lifestyle Risk Factors}

Study participants were interviewed during the examination about socio-demographic, health related information and reproductive history (parity and menarche). Body mass index (BMI) was calculated as current weight in kilograms divided by square of height expressed in meters. Any missing survey data were subsequently completed using patient's query.

\subsection{Genomic DNA Isolation}

Genomic DNA was extracted from peripheral blood collected in the presence of anti-coagulant (EDTA) using PureLink Genomic DNA Mini Kit (Thermo Fisher Scientific, Waltham, MA, USA) and stored at $-70{ }^{\circ} \mathrm{C}$. The quality and quantity of DNA was estimated spectrophotometrically with BioPhotometer plus (Eppendorf, Hamburg, Germany). DNA samples were characterized with A260 nm/A280 nm ratio, which was in the range of 1.8-2.0.

\subsection{SNP Selection and Genotyping}

Eight SNPs in the TGFBR3 gene were selected according to NCBI SNPs database: $r 8883873$, $r s 2770186, r s 12141128, r s 12566180, r s 6680463, r s 1805110, r s 1805113, r s 2296621$. All SNPs were supposed to have minor allele frequency (MAF) $\geq 5 \%$ and localization assigned as $5^{\prime}$ regulatory region, intron or exon of the TGFBR3 gene, which is located on chromosome 1. Characteristics of studied SNPs are presented in Table 2. 
Table 1. Socio-demographic and clinical characteristics of investigated subjects.

\begin{tabular}{|c|c|c|c|}
\hline & Cases $(n=153)$ & Controls $(n=248)$ & $p$ \\
\hline \multicolumn{4}{|l|}{ Socio-Demographic Characteristics } \\
\hline AGE (years) ${ }^{a}$ & $62.1 \pm 8.6$ & $63.4 \pm 9.0$ & 0.1896 \\
\hline $\min$ & 35 & 35 & \\
\hline $\max$ & 85 & 85 & \\
\hline $35-44^{b}$ & $2(1.3)$ & $10(4.0)$ & \\
\hline $45-54^{b}$ & $25(16.3)$ & $36(14.5)$ & \\
\hline $55-64^{b}$ & $75(49.0)$ & $84(33.9)$ & \\
\hline $65-74^{b}$ & $38(24.8)$ & $78(31.5)$ & \\
\hline $74-85^{b}$ & $13(8.5)$ & $40(16.1)$ & 0.009 \\
\hline BMI $\left(\mathrm{kg} / \mathrm{m}^{2}\right)^{\mathrm{a}}$ & $28.5 \pm 6.6$ & $24.9 \pm 4.0$ & $<0.001$ \\
\hline obesity $\left(\mathrm{BMI}>30 \mathrm{~kg} / \mathrm{m}^{2}\right)^{b}$ & $56(36.6)$ & $11(4.4)$ & $<0.001$ \\
\hline Menarche (years) ${ }^{a}$ & $13.8 \pm 2.0$ & $11.9 \pm 1.6$ & $<0.001$ \\
\hline Parity (childbirths) ${ }^{a}$ & $1.9 \pm 1.4$ & $1.1 \pm 0.9$ & $<0.001$ \\
\hline \multicolumn{4}{|l|}{ Clinico-Pathological Characteristics } \\
\hline Histological Diagnosis & endometrial adenocarcinoma & & \\
\hline \multicolumn{4}{|l|}{ Tumor Stage ${ }^{c}$} \\
\hline $\mathrm{I}^{\mathrm{b}}$ & $89(58.2)$ & & \\
\hline $\mathrm{II}^{\mathrm{b}}$ & $38(24.8)$ & & \\
\hline III $^{b}$ & $18(11.8)$ & & \\
\hline $\mathrm{IV}^{\mathrm{b}}$ & $8(5.2)$ & & \\
\hline \multicolumn{4}{|l|}{ Histological Grade ${ }^{\mathrm{d}}$} \\
\hline $\mathrm{G} 1^{\mathrm{b}}$ & $37(24.2)$ & & \\
\hline $\mathrm{G} 2^{\mathrm{b}}$ & $94(61.4)$ & & \\
\hline $\mathrm{G}^{\mathrm{b}}$ & $22(14.4)$ & & \\
\hline \multicolumn{4}{|l|}{ Depth OF Myometrial Invasion } \\
\hline$<1 / 2^{\mathrm{b}}$ & $82(53.6)$ & & \\
\hline$>1 / 2^{b}$ & $71(46.4)$ & & \\
\hline \multicolumn{4}{|l|}{ Vascular Space Invasion } \\
\hline not present ${ }^{b}$ & $85(55.6)$ & & \\
\hline present ${ }^{b}$ & $23(15.0)$ & & \\
\hline data not available ${ }^{b}$ & $45(29.4)$ & & \\
\hline
\end{tabular}

BMI—body mass index, ${ }^{a}$ Mean \pm SD. ${ }^{b}$ Number of subjects (percent total). ${ }^{\mathrm{c}}$ International Federation of Gynecology and Obstetrics staging system (FIGO). ${ }^{\mathrm{d}}$ World Health Organization grading system.

Table 2. Characteristics of studied polymorphisms.

\begin{tabular}{cccc}
\hline rs Number & Polymorphism & Localization & Maf \\
\hline rs883873 & g. $92380302 \mathrm{~A}>\mathrm{G}$ & $5^{\prime}$ regulatory region & 0.1394 \\
$r s 2770186$ & g. $92378843 \mathrm{~T}>\mathrm{C}$ & $5^{\prime}$ regulatory region & 0.4730 \\
$r s 12141128$ & g. $92373747 \mathrm{~A}>\mathrm{G}$ & $5^{\prime}$ regulatory region & 0.4736 \\
$r s 12566180$ & c. $-114+2392 \mathrm{C}>\mathrm{T}$ & intron & 0.4209 \\
$r s 6680463$ & c. $-114+7008 \mathrm{C}>\mathrm{G}$ & intron & 0.4687 \\
$r s 1805110$ & c. $44 \mathrm{C}>\mathrm{T}$ (p.Ser15Phe) & exon & 0.1859 \\
$r s 1805113$ & c. $2025 \mathrm{~T}>\mathrm{C}(\mathrm{p} . \mathrm{Phe675}=)$ & exon & 0.2798 \\
$r s 2296621$ & c. $2285-99 \mathrm{G}>\mathrm{T}$ & intron & 0.1050 \\
\hline
\end{tabular}

Real-Time PCR method with TaqMan Genotyping Assays (Thermo Fisher Scientific, Waltham, MA, USA) was applied for SNPs genotyping. The characteristics and sequences of used TaqMan probes are shown in Supplementary Table S1. PCR amplifications were conducted in a total volume of $10 \mu \mathrm{L}$ and consisted of $5 \mu \mathrm{L}(2 \times)$ of TaqMan Genotyping Master Mix buffer (Thermo Fisher Scientific, Waltham, MA, USA), $0.25 \mu \mathrm{L}(40 \times)$ TaqMan Genotyping Assay (Thermo Fisher Scientific, Waltham, MA, USA) and $10 \mathrm{ng}$ of template DNA. Thermal conditions were as follows: initial denaturation at $95^{\circ} \mathrm{C}$ for $10 \mathrm{~min}$, followed by 40 cycles of sequential incubations at $95{ }^{\circ} \mathrm{C}$ for $15 \mathrm{~s}$ and at $60{ }^{\circ} \mathrm{C}$ for 
$1 \mathrm{~min}$ and final endpoint measurement of fluorescence. Real-Time PCR amplifications and allelic discrimination were performed using Mastercycler ${ }^{\circledR}$ ep realplex (Eppendorf, Hamburg, Germany).

\subsection{Expression of the TGFBR3 Gene}

Total RNA was extracted from frozen endometrial tissues using PureLink RNA Mini kit (Thermo Fisher Scientific, Waltham, MA, USA) according to dedicated protocol. The amount and quantity of isolated RNA was assessed spectrophotometrically with BioPhotometer plus (Eppendorf, Hamburg, Germany) based on A260 nm/A280 nm ratio, which was in the range 1.8-2.0. Total RNA $(1 \mu \mathrm{g})$ was transcribed using RevertAid ${ }^{\mathrm{TM}} \mathrm{H}$ Minus First Strand cDNA Synthesis kit (Thermo Fisher Scientific, Waltham, MA, USA) according to manufacturer's recommendation. cDNA synthesis was performed in Thermocycler 2720 (Applied Biosystems, Foster City, CA, USA) with the following incubations: $10 \mathrm{~min}$ at $25^{\circ} \mathrm{C}, 120 \mathrm{~min}$ at $37^{\circ} \mathrm{C}$ and $5 \mathrm{~min}$ at $85^{\circ} \mathrm{C}$. The obtained cDNA was stored at $-70^{\circ} \mathrm{C}$. Real time PCR was performed using TaqMan probes (Thermo Fisher Scientific, Waltham, MA, USA) in line with the manufacturer's protocol on Mastercycler ${ }^{\circledR}$ Epgradient S Realplex (Eppendorf, Hamburg, Germany) in the presence of TaqMan Gene Expression Master Mix Thermo Fisher Scientific, Waltham, MA, USA). GAPDH served as a reference gene. The catalogue numbers of probes were Hs00234259_m1 for TGFBR3 and Hs99999905_m1 for GAPDH. The relative expression level was normalized to GAPDH and was calculated using the following equation: $2^{-\Delta \mathrm{Ct}} \times 1000$.

\subsection{Statistical Analysis}

The genotype frequency was tested for agreement with Hardy-Weinberg equilibrium (HWE) and assessed by chi-square goodness-of-fit test. Case-control differences in genotype and allelic distribution were analyzed using Pearson's $\chi^{2}$ (chi-square) or Fisher's exact tests against the homozygote of the common allele as the reference group $(\mathrm{OR}=1.00)$. Dominant and recessive genetic models were also implemented in the analysis. Variants of homozygotes and heterozygotes were combined to evaluate the dominant effect. SNPs distribution and their association with the clinico-pathological parameters were evaluated by multiple logistic regression. Genotype and allelic associations with endometrial cancer risk were expressed as odds ratio (ORs) and $95 \%$ confidence interval (95\% CI) in crude and multivariate model including age, BMI, parity, and age at menarche.

Linkage disequilibrium (LD) and haplotypes distribution analysis were performed using the powerful online platform SHEsis (http://analysis.bio-X.cn/myAnalysis.php) [29]. Haplotypes with frequency less than 0.03 were excluded from the analysis. Bonferroni correction was applied for multiple comparisons of SNPs haplotypes.

To assess inter-group differences of socio-demographic parameters (age, BMI, parity and menarche), as well as the TGFBR3 gene expression levels between respective genotypes of the analyzed SNPs, the first Shapiro-Wilk test was applied to determine the normality of obtained data. Following, the statistical significance of difference was evaluated using either Student's t-test, for normally distributed data, or Mann-Whitney test, for non-normally distributed data. $p<0.05$ in a two-tailed test was considered statistically significant. A statistical analysis of obtained data was conducted using GraphPad Prism version 5.00 for Windows (GraphPad Software, La Jolla, CA, USA) and PQStat version 1.6.8 (PQStat Software, Poland).

\subsection{Bioinformatic Analysis}

The functional consequences of significant SNPs were examined in RegulomeDB, which is a public database dedicated for noncoding SNP and annotates SNPs with known and putative regulatory elements in non-coding regions of human genome, such as regulatory DNA elements including regions of DNAase hypersensitivity, binding sites of transcription factors, and promoter regions that have been biochemically characterized to regulate transcription. RegulomeDB annotations are based on an integration of data from ENCODE project and other published literature, combined together 
by self-developed score system ranging from 1-6. A higher rank corresponds to a less functional significance [30].

\section{Results}

\subsection{SNPs Association with EC}

Eight single nucleotide polymorphisms in the TGFBR3 gene and their association with EC risk and invasiveness were evaluated. Three of analyzed polymorphisms, i.e., rs883873 (g.92380302A > G), rs2770186 (g.92378843T > C) and $r s 12141128$ (g.92373747A > G) are located in $5^{\prime}$ regulatory region, whereas the other five polymorphisms, i.e., rs12566180 (c. $-114+2392 \mathrm{C}>\mathrm{T}$ ), rs6680463 (c. $-114+7008 \mathrm{C}$ > G), rs1805110 (p.Ser15Phe), rs1805113 (p.Phe675=) and rs2296621 (c.2285 - 99G > T) are located downstream start codon of the TGFBR3 gene.

Based on a comparison of 153 women diagnosed with endometrial cancer and 248 healthy controls, we found significant differences in the distribution of the three studied SNPs (Table 3) adjusted to the following covariates, i.e., age, BMI, menarche and parity. Significant differences between endometrial cancer patients and control women were noted in body mass index (BMI; $p<0.001$ ), menarche $(p<0.001)$ and parity $(p<0.001)$. In addition, the subjects' age showed significant differences between case and control group when analyzed in 10 years subgroups $(p=0.009)$ (Table 1$)$. Accordingly, age, BMI, menarche and parity were selected as main covariates in further analysis. All studied SNPs were in Hardy-Weinberg equilibrium (HWE) except polymorphic site $r s 1805110$ (p.Ser15Phe), which was excluded from further analysis. The obtained results indicate that the polymorphisms of the highest importance for the increased endometrial cancer risk are $r s 12566180($ c. $-114+2392 \mathrm{C}>\mathrm{T}$ ), $r s 6680463$ (c. $-114+7008 \mathrm{C}>\mathrm{G}$ ) and $r s 2296621$ (c.2285 - 99G > T). SNPs, $r s 12566180$ (c. $-114+2392 \mathrm{C}>$ $\mathrm{T}$ ) and $r s 6680463$ (c. $-114+7008 \mathrm{C}>\mathrm{G}$ ) were found to be more frequent as heterozygous variants in the study group as compared to the controls with respective frequencies $55.6 \% \mathrm{vs} .44 .0 \%(p=0.0177)$ and $58.2 \%$ vs. $45.2 \%(p=0.0120)$, increasing the risk of endometrial cancer about 2.3 times. In turn, the polymorphic site $r s 2296621$ (c.2285 - 99G > T) was found to be 6.4-fold more frequent in the case of study group compared to the controls $(4.6 \%$ vs. $0.8 \%, p=0.0317$ ) as homozygous variant TT (Table 3 ).

Analysis of significantly altered SNPs in the cancer group in the context of clinico-pathological parameters revealed that in the case of $r s 2296621$ (c.2285-99G > T) the genotype GT and allele T are associated with an increased histological grade according to the WHO grading system (G3 vs. G1/2). The GT genotype was observed in $54.5 \%$ of high-graded tumors (G3) compared to $23.7 \%$ of less-graded $(\mathrm{G} 1 / 2)(\mathrm{OR}=4.04 ; 95 \% \mathrm{CI}=1.56-10.51 ; p=0.0026)$. Respectively, allele T carriers demonstrated G3 tumors more frequent than $\mathrm{G} 1 / 2$, i.e., $31.8 \%$ vs. $16.4 \%(\mathrm{OR}=2.38 ; 95 \% \mathrm{CI}=1.16-4.85 ; p=0.0151)$ (Supplementary Table S2).

Linkage disequilibrium (LD) analysis revealed that among eight studied SNPs in the TGFBR3 gene, four of them were in high $\operatorname{LD}\left(\mathrm{r}^{2} \geq 0.8\right)$ (Figure 1) and were arranged in two haploblocks constructed by $r s 2770186 / r s 12141128$ and $r s 12566180 / r s 6680463$. The frequency of haplotypes $r s 12566180 / r s 6680463$ $\mathrm{C} / \mathrm{C}$ and $\mathrm{T} / \mathrm{G}$ were significantly higher in endometrial cancer patients as compared to healthy controls: for $\mathrm{C} / \mathrm{C}$ haplotype 0.038 vs. $0.008(\mathrm{OR}=4.82 ; 95 \% \mathrm{CI}=1.54-15.07 ; p=0.0116$-Bonferroni corrected) and for $\mathrm{T} / \mathrm{G}$ haplotype 0.045 vs. $0.014(\mathrm{OR}=3.25 ; 95 \% \mathrm{CI}=1.29-8.15 ; p=0.0328$-Bonferroni corrected $)$, respectively (Table 4 ). 
Table 3. Genotype distribution and allelic frequencies of investigated SNPs in the TGFBR3 gene for women with diagnosed endometrial cancer and healthy controls.

\begin{tabular}{|c|c|c|c|c|c|c|c|c|c|c|c|}
\hline \multirow{2}{*}{ SNP Genotype/Allele } & \multicolumn{2}{|c|}{ Cancer $(n=123)$} & \multicolumn{2}{|c|}{ Control $(n=248)$} & \multirow[t]{2}{*}{$\mathrm{OR}^{\mathrm{a}}$} & \multirow[t]{2}{*}{$95 \%$ CI } & \multirow[t]{2}{*}{$p$ Value } & \multirow[t]{2}{*}{$\mathrm{OR}^{\mathrm{b}}$} & \multirow[t]{2}{*}{$95 \%$ CI } & \multirow[t]{2}{*}{$p$ Value } & \multirow[t]{2}{*}{ HWE $^{\mathrm{C}}$} \\
\hline & Number & Frequency (\%) & Number & Frequency (\%) & & & & & & & \\
\hline \multicolumn{12}{|l|}{$\begin{array}{l}\text { rs } 883873 \\
(\mathrm{~g} .92380302 \mathrm{~A}>\mathrm{G})\end{array}$} \\
\hline AA & 107 & 69.9 & 200 & 80.6 & 1.00 & (ref.) & & 1.00 & (ref.) & & \\
\hline AG & 45 & 29.4 & 47 & 19.0 & 1.79 & $1.12-2.87$ & 0.0149 & 1.26 & $0.68-2.33$ & 0.4607 & 0.3110 \\
\hline GG & 1 & 0.7 & 1 & 0.4 & 1.87 & $0.12-30.18$ & 1 & - & - & 1 & \\
\hline \multicolumn{12}{|c|}{$\chi^{2}=6.049 ; p=\mathbf{0 . 0 4 8 6}$} \\
\hline AG or GG vs. AA ${ }^{d}$ & 46 & & 48 & & 1.79 & $1.12-2.86$ & 0.0139 & 1.28 & $0.70-2.37$ & 0.4242 & \\
\hline AG or AA vs. GG ${ }^{\mathrm{e}}$ & 152 & & 247 & & 0.62 & $0.04-9.91$ & 1 & - & - & - & \\
\hline A & 259 & 84.6 & 447 & 90.1 & 0.60 & $0.39-0.93$ & 0.0203 & 0.77 & $0.42-1.40$ & 0.3846 & \\
\hline G & 47 & 15.4 & 49 & 9.9 & 1.66 & $1.08-2.54$ & 0.0203 & 1.31 & $0.72-2.39$ & 0.3846 & \\
\hline \multicolumn{12}{|l|}{$\begin{array}{l}r s 2770186 \\
(\text { g. } 92378843 \mathrm{~T}>\mathrm{C})\end{array}$} \\
\hline $\mathrm{TT}$ & 22 & 14.4 & 46 & 18.5 & 1.00 & (ref.) & & 1.00 & (ref.) & & \\
\hline $\mathrm{TC}$ & 89 & 58.2 & 120 & 48.4 & 1.55 & $0.87-2.76$ & 0.1345 & 1.54 & $0.74-3.22$ & 0.2469 & 0.8572 \\
\hline $\mathrm{CC}$ & 42 & 27.5 & 82 & 33.1 & 1.07 & $0.57-2.01$ & 0.8231 & 1.09 & $0.49-2.41$ & 0.8286 & \\
\hline \multicolumn{12}{|c|}{$\chi^{2}=3.672 ; p=0.1595$} \\
\hline TC or CC vs. TT ${ }^{d}$ & 131 & & 202 & & 1.36 & $0.78-2.36$ & 0.2794 & 1.27 & $0.73-2.23$ & 0.3961 & \\
\hline TC or TT vs. CC ${ }^{\mathrm{e}}$ & 111 & & 166 & & 1.31 & $0.84-2.03$ & 0.2367 & 1.35 & $0.67-2.73$ & 0.3930 & \\
\hline $\mathrm{T}$ & 133 & 43.5 & 212 & 42.7 & 1.03 & $0.77-1.37$ & 0.8415 & 1.02 & $0.70-1.50$ & 0.9100 & \\
\hline $\mathrm{C}$ & 173 & 56.5 & 284 & 57.3 & 0.97 & $0.73-1.29$ & 0.8415 & 0.98 & $0.67-1.44$ & 0.9100 & \\
\hline
\end{tabular}


Table 3. Cont.

\begin{tabular}{|c|c|c|c|c|c|c|c|c|c|c|c|}
\hline \multirow{2}{*}{ SNP Genotype/Allele } & \multicolumn{2}{|c|}{ Cancer $(n=123)$} & \multicolumn{2}{|c|}{ Control $(n=248)$} & \multirow[t]{2}{*}{$\mathrm{OR}^{\mathrm{a}}$} & \multirow[t]{2}{*}{$95 \% \mathrm{CI}$} & \multirow[t]{2}{*}{$p$ Value } & \multirow[t]{2}{*}{$\mathrm{OR}^{\mathrm{b}}$} & \multirow[t]{2}{*}{$95 \%$ CI } & \multirow[t]{2}{*}{$p$ Value } & \multirow[t]{2}{*}{ HWE } \\
\hline & Number & Frequency (\%) & Number & Frequency (\%) & & & & & & & \\
\hline \multicolumn{12}{|l|}{$\begin{array}{l}\text { rs12141128 } \\
(\mathrm{g} .92373747 \mathrm{~A}>\mathrm{G})\end{array}$} \\
\hline AA & 23 & 15.0 & 49 & 19.8 & 1.00 & (ref.) & & 1.00 & (ref.) & & \\
\hline AG & 88 & 57.5 & 118 & 47.6 & 1.59 & $0.90-2.80$ & 0.1082 & 1.65 & $0.80-3.38$ & 0.1742 & 0.6113 \\
\hline GG & 42 & 27.5 & 81 & 32.7 & 1.10 & $0.59-2.05$ & 0.7518 & 1.14 & $0.52-2.47$ & 0.7418 & \\
\hline \multicolumn{12}{|c|}{$\chi^{2}=3.833 ; p=0.1471$} \\
\hline AG or GG vs. AA ${ }^{d}$ & 130 & & 199 & & 1.39 & $0.81-2.39$ & 0.2318 & 1.43 & $0.72-2.83$ & 0.3018 & \\
\hline AG or AA vs. GG ${ }^{\mathrm{e}}$ & 111 & & 167 & & 1.28 & $0.82-2.00$ & 0.2713 & 1.27 & $0.72-2.23$ & 0.4023 & \\
\hline A & 134 & 43.8 & 216 & 43.5 & 1.01 & $0.76-1.35$ & 1.0000 & 1.00 & $0.68-1.46$ & 0.9920 & \\
\hline G & 172 & 56.2 & 280 & 56.5 & 0.99 & $0.74-1.32$ & 1.0000 & 1.00 & $0.69-1.46$ & 0.9920 & \\
\hline \multicolumn{12}{|l|}{$\begin{array}{l}r s 12566180 \\
(\text { c. }-114+2392 C>T)\end{array}$} \\
\hline $\mathrm{CC}$ & 30 & 19.6 & 68 & 27.4 & 1.00 & (ref.) & & 1.00 & (ref.) & & \\
\hline CT & 85 & 55.6 & 109 & 44.0 & 1.77 & $1.06-2.96$ & 0.0393 & 2.22 & $1.15-4.30$ & 0.0177 & 0.0570 \\
\hline $\mathrm{TT}$ & 38 & 24.8 & 71 & 28.6 & 1.21 & $0.68-2.17$ & 0.5169 & 1.18 & $0.58-2.41$ & 0.6484 & \\
\hline \multicolumn{12}{|c|}{$\chi^{2}=5.497 ; p=0.0640$} \\
\hline CT or CC vs. TT e & 115 & & 177 & & 1.21 & $0.77-1.92$ & 0.4062 & 1.42 & $0.80-2.51$ & 0.2256 & \\
\hline C & 145 & 47.4 & 245 & 49.4 & 0.92 & $0.69-1.23$ & 0.5777 & 0.95 & $0.67-1.35$ & 0.7761 & \\
\hline $\mathrm{T}$ & 161 & 52.6 & 251 & 50.6 & 1.08 & $0.81-1.44$ & 0.5777 & 1.05 & $0.74-1.50$ & 0.7761 & \\
\hline \multicolumn{12}{|l|}{$\begin{array}{l}\text { rs6680463 } \\
\text { (c. }-114+7008 \mathrm{C}>\mathrm{G})\end{array}$} \\
\hline GG & 29 & 19.0 & 68 & 27.4 & 1.00 & (ref.) & & 1.00 & (ref.) & & \\
\hline GC & 89 & 58.2 & 112 & 45.2 & 1.86 & $1.11-3.12$ & 0.0174 & 2.34 & $1.20-4.53$ & 0.0120 & 0.1275 \\
\hline $\mathrm{CC}$ & 35 & 22.9 & 68 & 27.4 & 1.21 & $0.67-2.19$ & 0.5376 & 1.09 & $0.53-2.24$ & 0.8243 & \\
\hline \multicolumn{12}{|c|}{$\chi^{2}=6.758 ; p=\mathbf{0 . 0 3 4 1}$} \\
\hline GC or CC vs. GG d & 124 & & 180 & & 1.61 & $0.99-2.64$ & 0.0544 & 1.74 & $0.95-3.20$ & 0.0749 & \\
\hline GC or GG vs. CC ${ }^{e}$ & 118 & & 180 & & 1.27 & $0.80-2.04$ & 0.3125 & 1.60 & $0.90-2.86$ & 0.1114 & \\
\hline G & 147 & 48.0 & 248 & 50.0 & 0.92 & $0.70-1.23$ & 0.5902 & 0.99 & $0.69-1.41$ & 0.9470 & \\
\hline $\mathrm{C}$ & 159 & 52.0 & 248 & 50.0 & 1.08 & $0.81-1.44$ & 0.5902 & 1.01 & $0.71-1.45$ & 0.9470 & \\
\hline
\end{tabular}


Table 3. Cont.

\begin{tabular}{|c|c|c|c|c|c|c|c|c|c|c|c|}
\hline \multirow{2}{*}{ SNP Genotype/Allele } & \multicolumn{2}{|c|}{ Cancer $(n=123)$} & \multicolumn{2}{|c|}{ Control $(n=248)$} & \multirow[t]{2}{*}{$\mathrm{OR}^{\mathrm{a}}$} & \multirow[t]{2}{*}{$95 \%$ CI } & \multirow[t]{2}{*}{$p$ Value } & \multirow[t]{2}{*}{$\mathrm{OR}^{\mathrm{b}}$} & \multirow[t]{2}{*}{$95 \%$ CI } & \multirow[t]{2}{*}{$p$ Value } & \multirow[t]{2}{*}{ HWE } \\
\hline & Number & Frequency (\%) & Number & Frequency (\%) & & & & & & & \\
\hline \multicolumn{12}{|l|}{$\begin{array}{l}\text { rs1805110 c. } 44 C>T \\
\text { (p.Ser15Phe) }\end{array}$} \\
\hline $\mathrm{CC}$ & 0 & 0.0 & 0 & 0.0 & - & - & - & - & - & - & \\
\hline CT & 112 & 73.2 & 212 & 85.5 & 0.46 & $0.28-0.77$ & 0.0024 & 0.79 & $0.42-1.50$ & 0.4771 & $<0.001$ \\
\hline TT & 41 & 26.8 & 36 & 14.5 & 2.16 & $1.30-3.56$ & 0.0024 & 1.26 & $0.66-2.39$ & 0.4771 & \\
\hline \multicolumn{12}{|c|}{$\chi^{2}=9.199 ; p=\mathbf{0 . 0 1 0 0}$} \\
\hline CT or TT vs. CC ${ }^{d}$ & 153 & & 248 & & - & - & - & - & - & - & \\
\hline CT or CC vs. TT ${ }^{\mathrm{e}}$ & 112 & & 212 & & 0.46 & $0.28-0.77$ & 0.0024 & 0.79 & $0.42-1.50$ & 0.4771 & \\
\hline C & 112 & 36.6 & 212 & 42.7 & 0.77 & $0.58-1.04$ & 0.0853 & 0.79 & $0.42-1.50$ & 0.4771 & \\
\hline $\mathrm{T}$ & 194 & 63.4 & 284 & 57.3 & 1.29 & $0.96-1.73$ & 0.0853 & 1.26 & $0.66-2.39$ & 0.4771 & \\
\hline \multicolumn{12}{|l|}{$\begin{array}{l}r s 1805113 \text { c.2025T }>C \\
\text { (p.Phe675=) }\end{array}$} \\
\hline $\mathrm{TT}$ & 56 & 36.6 & 87 & 35.1 & 1.00 & (ref.) & & 1.00 & (ref.) & & \\
\hline $\mathrm{TC}$ & 68 & 44.4 & 123 & 49.6 & 0.86 & $0.55-1.34$ & 0.5055 & 0.62 & $0.34-1.12$ & 0.1115 & 0.6117 \\
\hline $\mathrm{CC}$ & 29 & 19.0 & 38 & 15.3 & 1.19 & $0.66-2.14$ & 0.5707 & 0.93 & $0.44-1.96$ & 0.8513 & \\
\hline \multicolumn{12}{|c|}{$\chi^{2}=1.336 ; p=0.5127$} \\
\hline TC or CC vs. TT ${ }^{d}$ & 97 & & 161 & & 0.94 & $0.62-1.42$ & 0.7518 & 0.70 & $0.40-1.21$ & 0.2001 & \\
\hline TC or TT vs. CC ${ }^{\mathrm{e}}$ & 124 & & 210 & & 0.77 & $0.45-1.32$ & 0.3438 & 0.81 & $0.42-1.57$ & 0.5405 & \\
\hline $\mathrm{T}$ & 180 & 58.8 & 297 & 59.9 & 0.96 & $0.72-1.28$ & 0.7642 & 1.10 & $0.77-1.58$ & 0.6083 & \\
\hline $\mathrm{C}$ & 126 & 41.2 & 199 & 40.1 & 1.04 & $0.78-1.40$ & 0.7642 & 0.91 & $0.63-1.31$ & 0.6083 & \\
\hline \multicolumn{12}{|l|}{$\begin{array}{l}r s 2296621 \\
c .2285-99 \mathrm{G}>\mathrm{T}\end{array}$} \\
\hline GG & 103 & 67.3 & 178 & 71.8 & 1.00 & (ref.) & & 1.00 & (ref.) & & \\
\hline GT & 43 & 28.1 & 68 & 27.4 & 1.09 & $0.70-1.72$ & 0.6985 & 0.87 & $0.49-1.53$ & 0.6226 & 0.0988 \\
\hline TT & 7 & 4.6 & 2 & 0.8 & 6.05 & $1.23-29.66$ & 0.0178 & 6.40 & $1.18-34.84$ & 0.0317 & \\
\hline \multicolumn{12}{|c|}{$\chi^{2}=6.272 ; p=\mathbf{0 . 0 4 3 5}$} \\
\hline GT or TT vs. GG ${ }^{\mathrm{d}}$ & 50 & & 70 & & 1.23 & $0.80-1.91$ & 0.3428 & 1.04 & $0.60-1.80$ & 0.8951 & \\
\hline GT or GG vs. TT ${ }^{\mathrm{e}}$ & 146 & & 246 & & 0.17 & $0.03-0.83$ & 0.0178 & 0.15 & $0.03-0.80$ & 0.0267 & \\
\hline G & 249 & 81.4 & 424 & 85.5 & 0.74 & $0.51-1.09$ & 0.1237 & 0.80 & $0.50-1.30$ & 0.3703 & \\
\hline $\mathrm{T}$ & 57 & 18.6 & 72 & 14.5 & 1.35 & $0.92-1.97$ & 0.1237 & 1.24 & $0.77-2.00$ & 0.3703 & \\
\hline
\end{tabular}

${ }^{a}$ Crude. ${ }^{b}$ Adjusted for age, BMI, parity and menarche. ${ }^{\mathrm{c}}$ Hardy-Weinberg equilibrium test for controls. ${ }^{\mathrm{d}}$ Testing dominant genetic model. ${ }^{\mathrm{e}}$ Testing recessive genetic model; $p<0.05$ along with corresponding ORs are in bold. 

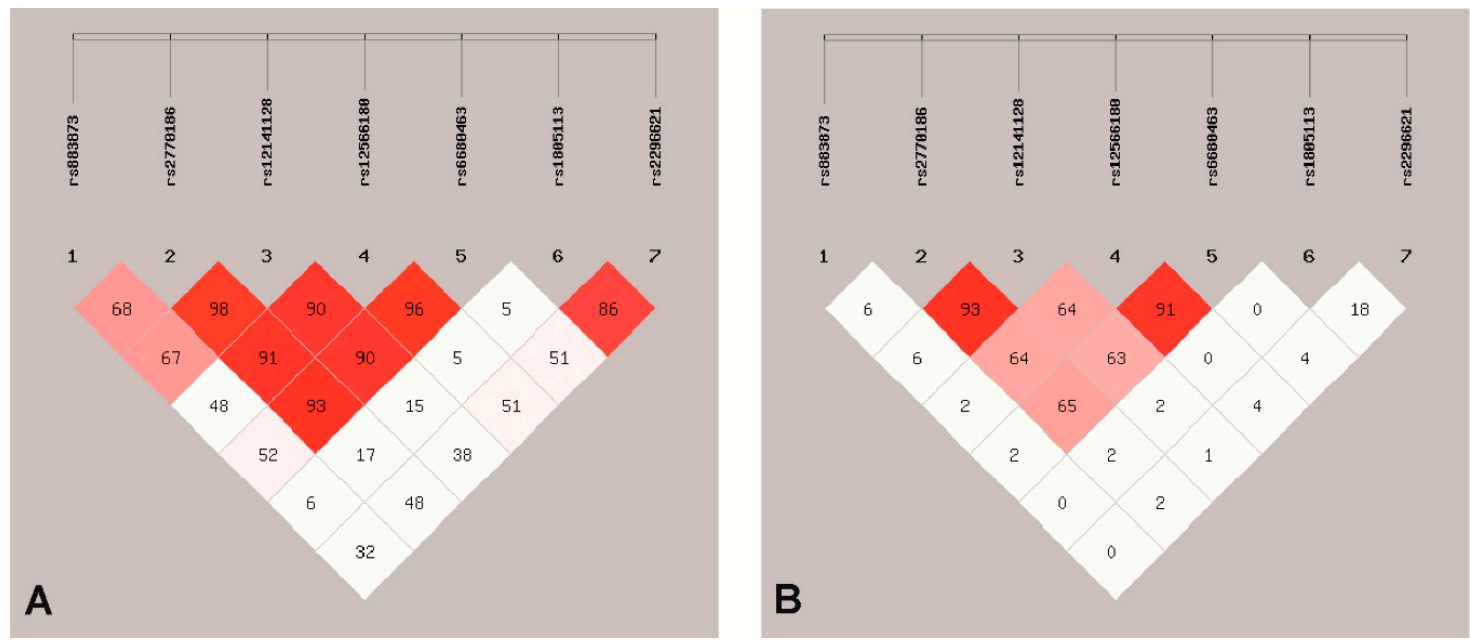

Figure 1. Analysis of linkage disequilibrium of $r s 883873, r s 2770186, r s 12141128, r s 12566180, r s 6680463$, rs1805113, rs2296621 polymorphisms in the TGFBR3 gene. (A). Pairwise $\mathrm{D}^{\prime}$ values $\times 100$. (B). Pairwise $\mathrm{r}^{2}$ values $\times 100 . \mathrm{r}^{2} \geq 0.8$-high LD.

Table 4. Distribution of combined haplotype of $r s 12566180, r s 6680463$ and $r s 2296621$ polymorphisms and risk of the endometrial cancer. (Bold indicates statistically significant results.).

\begin{tabular}{|c|c|c|c|c|c|c|c|}
\hline \multirow{2}{*}{$\begin{array}{l}\text { Combined } \\
\text { Haplotype }\end{array}$} & \multicolumn{2}{|c|}{ Cancer } & \multicolumn{2}{|c|}{ Control } & \multirow[t]{2}{*}{ OR } & \multirow[t]{2}{*}{$95 \% \mathrm{CI}$} & \multirow{2}{*}{$\begin{array}{c}p \text { Value (Bonferron } \\
\text { Corrected) }\end{array}$} \\
\hline & Number & $\begin{array}{c}\text { Frequency } \\
\quad(\%)\end{array}$ & Number & $\begin{array}{l}\text { Frequency } \\
(\%)\end{array}$ & & & \\
\hline \multicolumn{8}{|c|}{ rs2770186/rs12141128 } \\
\hline $\mathrm{C} / \mathrm{A}$ & 1 & 0.003 & 6.02 & 0.012 & - & - & - \\
\hline $\mathrm{C} / \mathrm{G}$ & 172 & 0.562 & 277.98 & 0.560 & 0.98 & $0.73-1.30$ & 1.0000 \\
\hline $\mathrm{T} / \mathrm{A}$ & 133 & 0.435 & 209.98 & 0.423 & 1.02 & $0.77-1.37$ & 1.0000 \\
\hline $\mathrm{T} / \mathrm{G}$ & 0 & 0.000 & 2.02 & 0.004 & - & - & - \\
\hline \multicolumn{8}{|c|}{ rs12566180/rs6680463 } \\
\hline $\mathrm{C} / \mathrm{C}$ & 11.69 & 0.038 & 4.05 & 0.008 & 4.82 & $1.54-15.07$ & 0.0116 \\
\hline $\mathrm{C} / \mathrm{G}$ & 133.31 & 0.436 & 240.95 & 0.486 & 0.82 & $0.61-1.09$ & 0.6676 \\
\hline $\mathrm{T} / \mathrm{C}$ & 147.31 & 0.481 & 243.95 & 0.492 & 0.96 & $0.72-1.28$ & 1.0000 \\
\hline $\mathrm{T} / \mathrm{G}$ & 13.69 & 0.045 & 7.05 & 0.014 & 3.25 & $1.29-8.15$ & 0.0328 \\
\hline
\end{tabular}

3.2. Association of the TGFBR3 Gene SNPs and Betaglycan mRNA Expression-Genotype-Phenotype Analysis

Figure 2 shows the mRNA expression level of the TGFBR3 gene in $50 \mathrm{EC}$ patients in relation to the genotypes of eight studied SNPs of the TGFBR3 gene. Six SNPs of the TGFBR3 gene were found to modulate its expression. The significant down-regulation of TGFBR3 mRNA was observed in the case of homozygous variant of $r s 2770186$ for genotype CC $(p<0.05)$, rs12141128 for genotype GG $(p<0.05)$, rs1805110 for phenotype variant Phe/Phe $(p<0.01)$ and $r s 2296621$ for genotype TT $(p<0.05)$ as compared to heterozygous variants. Furthermore, $r s 883873$ polymorphism for genotype AG $(p<0.05)$, rs12566180 for genotype TT $(p<0.01)$ and $r s 2296621$ for genotype TT $(p<0.001)$ demonstrated a statistically lower TGFBR3 mRNA level with regard to the wild-type carriers. 

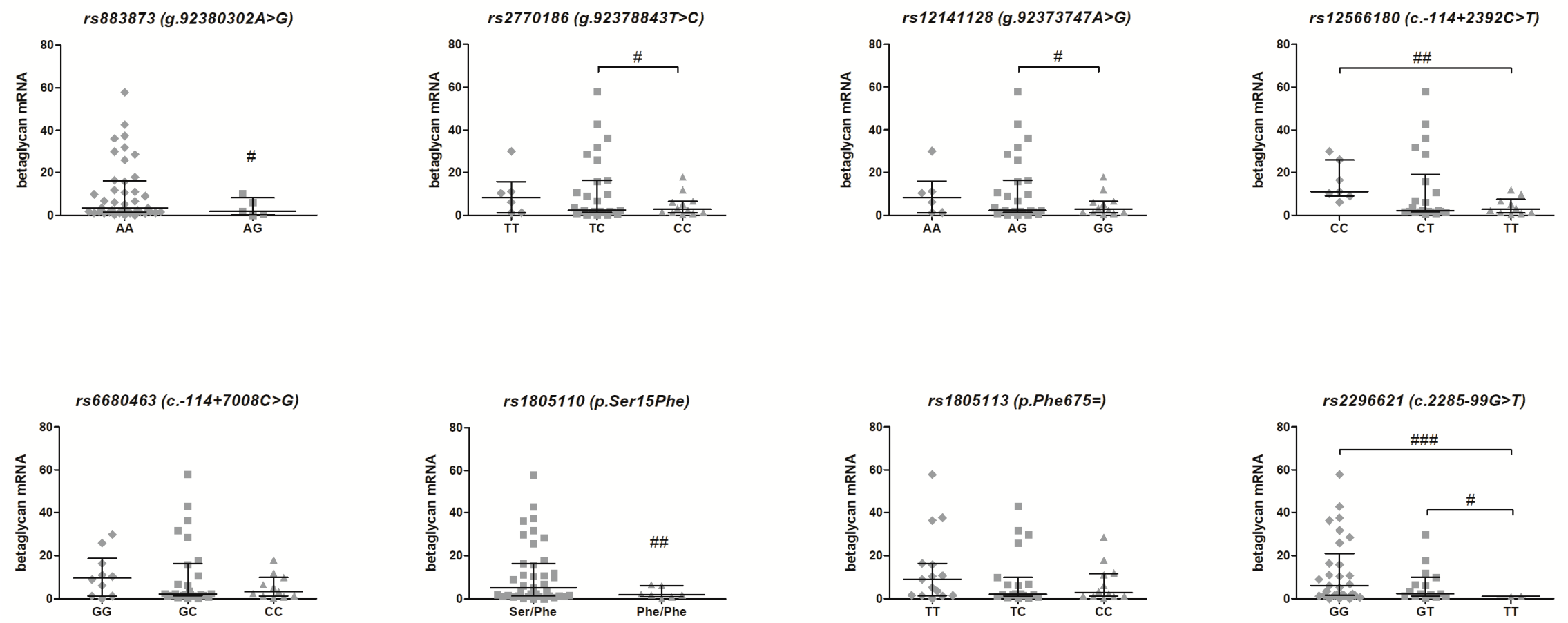

Figure 2. Impact of single-nucleotide polymorphisms related to the TGFBR3 gene on betaglycan mRNA expression in women with EC. Data are shown as scatter dot plots, horizontal lines represent median, whereas whiskers correspond to interquartile range. ${ }^{\#} p<0.05,{ }^{\# \#} p<0.01$, \#\#\# $p<0.001$. 


\section{Discussion}

Transforming growth factors $\beta$ isoforms, i.e., TGF $\beta 1$, TGF $\beta 2$ and TGF $\beta 3$, belong to a large superfamily of cytokines, which were identified due to their important role in normal development and homeostasis. TGF $\beta$ pathway controls many opposed processes, which is known as the pleiotropic effect on cell and tissue physiology. TGF $\beta$ cascade is responsible for both suppression or induction of cell proliferation and apoptosis, as well as regulates autophagy, cell dormancy and senescence. Deregulation of TGF $\beta$ signaling, both at induction step and downstream signaling contributes to developmental anomalies and diseases, in particular fibrosis and cancer, which is associated with overexpression of TGF $\beta$ isoforms [31,32]. Moreover, in cancer cells, disturbed signal mediation in TGF $\beta$ pathway triggers its role from a tumor suppressor, early in neoplastic transformation, to a cancer-promoting and metastatic agent in advanced clinical stages of the disease [33].

In cancer cells, alteration of TGF $\beta$ signaling, which plays the pleiotropic role during carcinogenesis, may be influenced by gene polymorphism. Knowledge of the potential role of polymorphism of the TGFBR3 gene encoding betaglycan and its relation to development of EC is elusive. Risk of endometrial cancer development is highly associated with different lifestyle and socio-demographic factors including obesity, onset of menarche, reproductive history, ethnicity and patient's age [34-40]. Overweight, young age at menarche or nulliparity cause prolonged exposure to estrogens, which possess high proliferative potential, in particular to uterus lining. In the case of obesity, unopposed estrogen stimulation is the result of reduction of progesterone synthesis and higher levels of circulating estrogens. During pregnancy, the estrogen exposure is balanced by the shift toward progesterone signaling. For this reason, nulliparous women have a higher risk of developing endometrial cancer due to extended estrogen stimuli. Moreover, the increased number of births shows a protective effect on endometrial cancer occurrence [40-42]. Our study has demonstrated that $r s 12566180$ (c. $-114+$ $2392 \mathrm{C}>\mathrm{T}$ ), $r s 6680463$ (c. $-114+7008 \mathrm{C}>\mathrm{G}$ ) and $r s 2296621$ (c.2285 - 99G > T) polymorphisms of the TGFBR3 gene are associated with increased risk of EC, both as crude or adjusted for socio-demographic risk factors, such as age, body mass index (BMI), menarche and parity. None of the patients had received EC related hormonal therapy prior to surgery; however, the patients' records concerning hormonal replacement therapy as well as Lynch syndrome history were not available. In spite of the fact, that Lynch syndrome significantly increases the risk of EC to $25-60 \%$, its impact on development of EC can be excluded as its occurrence ranges between $0.5 \%$ and $4.6 \%$ of all EC cases $[9,10]$.

The $r s 12566180$ (c.-114 + 2392C > T) and $r s 2296621$ (c.2285 - 99G > T) polymorphisms significantly altered in endometrial cancer are located within intronic regions of the TGFBR3 gene, which may indicate their potential impact on transcription and stability of the primary transcript. Obtained results suggest that studied SNPs are involved in the observed betaglycan down-regulation in endometrial cancer; however, the only one of them, i.e., rs2296621 (c.2285 - 99G > T), seems to be related to pronounced tumor aggressiveness. Bioinformatic analysis using RegulomeDB showed that $r s 12566180$ $($ c. $-114+2392 \mathrm{C}>\mathrm{T}$ ) and $r s 6680463$ (c. $-114+7008 \mathrm{C}>\mathrm{G}$ ) have a score of 4 , whereas $r s 2296621$ (c.2285 - 99G > T) has a score of 2 [30]. Taking into account SNPs case-control study, haplotype analysis and genotype-phenotype findings, the observed results indicate that $r s 12566180$ (c.-114 + 2392C > T), $r s 6680463$ (c. $-114+7008 \mathrm{C}>\mathrm{G}$ ) and $r s 2296621$ (c.2285 - 99G > T) could be regarded as potential markers for EC. However, further studies are required.

According to the literature data, polymorphism of the TGFBR3 gene is considered as a mechanism responsible for betaglycan down-regulation of HBV-infection related hepatocellular carcinoma and ovarian cancer [17,43-45]. Bae et al. [17] evaluated six SNPs, i.e., $r s 1805110$ (p.Ser15Phe), $r s 2810904$ (p.Ala72=), $r s 2306888$ (p.Ser173=), rs1805113 (p.Phe675=), $r s 284878$ (p.Thr749=) and newly identified SNP p.Thr711=, in the TGFBR3 gene in a group consisting of 67 patients with hepatocellular carcinoma. In their study, rs1805110 (p.Ser15Phe) polymorphism was found to be present at a high frequency, i.e., in about $98.5 \%$ of examined cancer samples; however, the lack of case-control comparison made it impossible to confirm the association between $r s 1805110$ (p.Ser15Phe) SNP occurrence and betaglycan down-regulation [17]. Similar results were presented by Xin et al. [45]. Among 16 different SNPs in 
genes encoding components of TGF $\beta$ pathway, i.e., TGF $\beta 1$, TGF $\beta R 1 / 2$ and betaglycan, significantly changed frequency of $r s 1805110$ polymorphic site was found to be associated with incidence of HBV-related hepatocellular carcinoma (T allele, $\mathrm{OR}=1.33 ; 95 \% \mathrm{CI}=1.09-1.63 ; p=0.005$ ) for male Chinese patients of Han ethnicity. According to the study by Kim et al. [43] rs1805113 (Phe676Phe) in exon 13 and $r s 1805117$ in $3^{\prime}$-UTR ( $p=0.009$ and $p=0.008$, respectively) polymorphisms were significantly associated with HBV clearance. In addition, Cox relative hazards analysis revealed that the GGTCAA haplotype of $r s 2306888, r s 1805112, r s 1805113, r s 284878, r s 1805117$ and $r s 1804506$ polymorphisms showed a significant association with the age of HCC occurrence among chronic HBV patients (relative hazard $=1.38 ; p=0.007$ ). In turn, the study presented by Charbonneau et al. [44] showed that in the case of mucinous invasive epithelial ovarian cancer (EOC), significantly altered distribution of polymorphisms rs12129174 (c.384 + 1320G > A) and rs4658265 (c.247 - 16378G > A), located in the introns of the TGFBR3 gene, was moderately correlated with patients' survival ( $r s 12129174-\mathrm{HR}=1.61 ; 95 \% \mathrm{CI}=1.18-2.19$; $p=0.0038 ; r s 4658265-\mathrm{HR}=1.56 ; 95 \% \mathrm{CI}=1.20-2.05 ; p=0.0012$ ).

Furthermore, besides above-mentioned relationship between SNPs of the TGFBR3 gene and neoplastic transformation, the importance of polymorphism in betaglycan encoding gene was reported for other non-cancerous diseases, i.e., premature ovarian failure (POF), testicular dysgenesis, sickle cell anemia, pulmonary emphysema and primary open angle glaucoma [46-51]. It is suggested that the TGFBR3 gene polymorphism may play a potential role in determining bone mineral density, as well as optic disc area parameters [52-54].

Interestingly, in our study, six out of eight analyzed SNPs of the TGFBR3 gene were found to have an impact on betaglycan expression in EC. Altered betaglycan expression may be responsible for impaired TGF $\beta$ signaling initiated by TGF $\beta$ isoforms and simultaneous redirection of this signal to Smad-independent pathways. TGFBR3 gene downregulation has been stated in the case of different cancers, and the observed decline in the expression of the TGFBR3 gene appears to be correlated with cancer progression, when tumor cells demonstrate an increase invasiveness and metastatic potential [17-23,25-28].

As previously described by different research groups, TGF $\beta$ signaling induced by TGF $\beta$ isoforms may be engaged in the induction of epithelial-mesenchymal transition (EMT). EMT is a biological process characterized by the reorganization of the epithelial tissue structure and is manifested by the acquisition of the mesenchymal phenotype resulting in the loss of polarity and adhesion by cells together with ability to migration and invasion. This process plays a vital role during physiological events, i.e., embryogenesis, organogenesis and morphogenesis of different tissues, wound healing, as well as inflammation. In cancer progression, EMT is responsible for the development of drug resistance and metastasis due to the increased cancer cell motility [55-57].

In summary, our study has demonstrated for the first time the role of the TGFBR3 gene polymorphism and its association with the increased risk of EC development. Moreover, we have shown that the TGFBR3 gene SNPs may modulate betaglycan expression at the transcriptomic level. Our findings contribute to a better understanding of the importance of gene polymorphism in the TGF $\beta$ signaling, especially at the level of signal initiation through TGF $\beta 2$ isoform mediated exclusively by betaglycan. Along with our previous findings concerning the significance of allelic loss in the TGFBR3 gene, where $\mathrm{LOH}$ was reported in $52 \%$ of examined cancer samples, SNPs may be an additional mechanism responsible for betaglycan deregulation in EC $[28,58]$. What is more, obtained results strongly support the view of individual variability among EC patients and suggest the necessity of developing personalized diagnostic and/or therapeutic approach in the treatment of endometrial cancer.

Supplementary Materials: Table S1: Characteristics and sequences of TaqMan probes used for genotyping of TGFBR3 gene; Table S2: The association between significantly altered SNPs, i.e., rs12566180, rs6680463 and rs2296621 polymorphisms and clinico-pathological parameters of studied cancer samples.

Author Contributions: Conception and design: P.K.Z., W.M.K.; collecting human samples and clinical findings, K.W.-K., A.B., A.S., M.B.; acquisition of data, P.K.Z., E.F., A.I.C.; analysis and interpretation of data, P.K.Z., W.M.K.; drafting the article or revising it critically for important intellectual content, P.K.Z., W.M.K., E.F., M.B., A.S., A.B.; 
final approval of the version to be published, P.K.Z., E.F., A.I.C., M.B., K.W.-K., A.B., A.S., W.M.K. All authors have read and agreed to the published version of the manuscript.

Funding: The work was supported by grant UMO-2011/01/N/NZ4/01723 (to PKZ) from The National Science Centre (NCN), Poland.

Conflicts of Interest: The authors declare no conflict of interest.

\section{References}

1. Ferlay, J.; Colombet, M.; Soerjomataram, I.; Mathers, C.; Parkin, D.M.; Piñeros, M.; Znaor, A.; Bray, F. Estimating the global cancer incidence and mortality in 2018: GLOBOCAN sources and methods. Int. J. Cancer 2019, 144, 1941-1953. [CrossRef]

2. Didkowska, J.; Wojciechowska, U.; Czaderny, K.; Olasek, P.; Ciuba, A. Cancer in Poland in 2017; Polish National Cancer Registry: Warsaw, Poland, 2019.

3. Bokhman, J.V. Two pathogenetic types of endometrial carcinoma. Gynecol. Oncol. 1983, 15, 10-17. [CrossRef]

4. Webb, P.M. Environmental (nongenetic) factors in gynecological cancers: Update and future perspectives. Future Oncol. 2015, 11, 295-307. [CrossRef] [PubMed]

5. Murali, R.; Soslow, R.A.; Weigelt, B. Classification of endometrial carcinoma: More than two types. Lancet Oncol. 2014, 15, e268-e278. [CrossRef]

6. Yen, T.T.; Wang, T.L.; Fader, A.N.; Shih, I.M.; Gaillard, S. Molecular Classification and Emerging Targeted Therapy in Endometrial Cancer. Int. J. Gynecol. Pathol. 2020, 39, 26-35. [CrossRef]

7. Lee, Y.C.; Lheureux, S.; Oza, A.M. Treatment strategies for endometrial cancer: Current practice and perspective. Curr. Opin. Obstet. Gynecol. 2017, 29, 47-58. [CrossRef]

8. Getz, G.; Gabriel, S.B.; Cibulskis, K.; Lander, E.; Sivachenko, A.; Sougnez, C.; Lawrence, M.; Kandoth, C.; Dooling, D.; Fulton, R.; et al. Integrated genomic characterization of endometrial carcinoma. Nature 2013, 497, 67-73. [CrossRef]

9. Bell, D.W.; Ellenson, L.H. Molecular Genetics of Endometrial Carcinoma. Annu. Rev. Pathol. Mech. Dis. 2019, 14, 339-367. [CrossRef]

10. Rossi, L.; Le Frere-Belda, M.A.; Laurent-Puig, P.; Buecher, B.; De Pauw, A.; Stoppa-Lyonnet, D.; Canlorbe, G.; Caron, O.; Borghese, B.; Colas, C.; et al. Clinicopathologic characteristics of endometrial cancer in lynch syndrome A French multicenter study. Int. J. Gynecol. Cancer 2017, 27, 953-960. [CrossRef]

11. Parekh, T.V.; Gama, P.; Wen, X.; Demopoulos, R.; Munger, J.S.; Carcangiu, M.L.; Reiss, M.; Gold, L.I. Transforming growth factor $\beta$ signaling is disabled early in human endometrial carcinogenesis concomitant with loss of growth inhibition. Cancer Res. 2002, 62, 2778-2790.

12. Piestrzeniewicz-Ulanska, D.; Brys, M.; Semczuk, A.; Jakowicki, J.A.; Krajewska, W.M. Expression of TGF- $\beta$ type I and II receptors in normal and cancerous human endometrium. Cancer Lett. 2002, 186, 231-239. [CrossRef]

13. Piestrzeniewicz-Ulanska, D.; Brys, M.; Semczuk, A.; Rechberger, T.; Jakowicki, J.A.; Krajewska, W.M. TGF- $\beta$ signaling is disrupted in endometrioid-type endometrial carcinomas. Gynecol. Oncol. 2004, 95, 173-180. [CrossRef] [PubMed]

14. Drabsch, Y.; Ten Dijke, P. TGF- $\beta$ signalling and its role in cancer progression and metastasis. Cancer Metastasis Rev. 2012, 31, 553-568. [CrossRef] [PubMed]

15. Gordon, K.J.; Blobe, G.C. Role of transforming growth factor- $\beta$ superfamily signaling pathways in human disease. Biochim. Biophys. Acta Mol. Basis Dis. 2008, 1782, 197-228. [CrossRef]

16. Cheifetz, S.; Andres, J.L.; Massagué, J. The transforming growth factor-beta receptor type III is a membrane proteoglycan. Domain structure of the receptor. J. Biol. Chem. 1988, 263, 16984-16991.

17. Bae, H.J.; Eun, J.W.; Noh, J.H.; Kim, J.K.; Jung, K.H.; Xie, H.J.; Park, W.S.; Lee, J.Y.; Nam, S.W. Down-regulation of transforming growth factor $\beta$ receptor type III in hepatocellular carcinoma is not directly associated with genetic alterations or loss of heterozygosity. Oncol. Rep. 2009, 22, 475-480. [CrossRef]

18. Bilandzic, M.; Chu, S.; Farnworth, P.G.; Harrison, C.; Nicholls, P.; Wang, Y.; Escalona, R.M.; Fuller, P.J.; Findlay, J.K.; Stenvers, K.L. Loss of betaglycan contributes to the malignant properties of human granulosa tumor cells. Mol. Endocrinol. 2009, 23, 539-548. [CrossRef]

19. Copland, J.A.; Luxon, B.A.; Ajani, L.; Maity, T.; Campagnaro, E.; Guo, H.; LeGrand, S.N.; Tamboli, P.; Wood, C.G. Genomic profiling identifies alterations in TGF $\beta$ signaling through loss of TGF $\beta$ receptor expression in human renal cell carcinogenesis and progression. Oncogene 2003, 22, 8053-8062. [CrossRef] 
20. Dong, M.; How, T.; Kirkbride, K.C.; Gordon, K.J.; Lee, J.D.; Hempel, N.; Kelly, P.; Moeller, B.J.; Marks, J.R.; Blobe, G.C. The type III TGF- $\beta$ receptor suppresses breast cancer progression. J. Clin. Investig. 2007, 117, 206-217. [CrossRef]

21. Finger, E.C.; Turley, R.S.; Dong, M.; How, T.; Fields, T.A.; Blobe, G.C. TßRIII suppresses non-small cell lung cancer invasiveness and tumorigenicity. Carcinogenesis 2008, 29, 528-535. [CrossRef]

22. Gordon, K.J.; Dong, M.; Chislock, E.M.; Fields, T.A.; Blobe, G.C. Loss of type III transforming growth factor beta receptor expression increases motility and invasiveness associated with epithelial to mesenchymal transition during pancreatic cancer progression. Carcinogenesis 2008, 29, 252-262. [CrossRef] [PubMed]

23. Hempel, N.; How, T.; Dong, M.; Murphy, S.K.; Fields, T.A.; Blobe, G.C. Loss of betaglycan expression in ovarian cancer: Role in motility and invasion. Cancer Res. 2007, 67, 5231-5238. [CrossRef] [PubMed]

24. Iolascon, A.; Giordani, L.; Borriello, A.; Carbone, R.; Izzo, A.; Tonini, G.P.; Gambini, C.; Della Ragione, F. Reduced expression of transforming growth factor-beta receptor type III in high stage neuroblastomas. Br. J. Cancer 2000, 82, 1171-1176. [CrossRef] [PubMed]

25. Liu, X.L.; Xiao, K.; Xue, B.; Yang, D.; Lei, Z.; Shan, Y.; Zhang, H.T. Dual role of TGFBR3 in bladder cancer. Oncol. Rep. 2013, 30, 1301-1308. [CrossRef]

26. Sharifi, N.; Hurt, E.M.; Kawasaki, B.T.; Farrar, W.L. TGFBR3 loss and consequences in prostate cancer. Prostate 2007, 67, 301-311. [CrossRef]

27. Turley, R.S.; Finger, E.C.; Hempel, N.; How, T.; Fields, T.A.; Blobe, G.C. The type III transforming growth factor-beta receptor as a novel tumor suppressor gene in prostate cancer. Cancer Res. 2007, 67, 1090-1098. [CrossRef]

28. Zakrzewski, P.K.; Mokrosinski, J.; Cygankiewicz, A.I.; Semczuk, A.; Rechberger, T.; Skomra, D.; Krajewska, W.M. Dysregulation of betaglycan expression in primary human endometrial carcinomas. Cancer Investig. 2011, 29, 137-142. [CrossRef]

29. Shi, Y.Y.; He, L. SHEsis, a powerful software platform for analyses of linkage disequilibrium, haplotype construction, and genetic association at polymorphism loci. Cell Res. 2005, 15, 97-98. [CrossRef]

30. Boyle, A.P.; Hong, E.L.; Hariharan, M.; Cheng, Y.; Schaub, M.A.; Kasowski, M.; Karczewski, K.J.; Park, J.; Hitz, B.C.; Weng, S.; et al. Annotation of functional variation in personal genomes using RegulomeDB. Genome Res. 2012, 22, 1790-1797. [CrossRef]

31. Akhurst, R.J. Targeting TGF- $\beta$ Signaling for Therapeutic Gain. Cold Spring Harb. Perspect. Biol. 2017, 9 , a022301. [CrossRef]

32. Zhang, Y.; Alexander, P.B.; Wang, X.F. TGF- $\beta$ family signaling in the control of cell proliferation and survival. Cold Spring Harb. Perspect. Biol. 2017, 9, a022145. [CrossRef] [PubMed]

33. Xie, F.; Ling, L.; Van Dam, H.; Zhou, F.; Zhang, L. TGF- $\beta$ signaling in cancer metastasis. Acta Biochim. Biophys. Sin. 2018, 50, 121-132. [CrossRef] [PubMed]

34. Jenabi, E.; Poorolajal, J. The effect of body mass index on endometrial cancer: A meta-analysis. Public Health 2015, 129, 872-880. [CrossRef] [PubMed]

35. Gao, Y.; Dai, X.; Chen, L.; Lee, A.C.; Tong, M.; Wise, M.; Chen, Q. Body Mass Index Is Positively Associated with Endometrial Cancer in Chinese Women, Especially Prior to Menopause. J. Cancer 2016, 7, 1169-1173. [CrossRef]

36. Althubiti, M. Mutation frequencies in endometrial cancer patients of different ethnicities and tumor grades: An analytical study. Saudi J. Med. Med. Sci. 2019, 7, 16. [CrossRef]

37. Park, S.L.; Goodman, M.T.; Zhang, Z.F.; Kolonel, L.N.; Henderson, B.E.; Setiawan, V.W. Body size, adult BMI gain and endometrial cancer risk: The multiethnic cohort. Int. J. Cancer 2010, 126, 490-499. [CrossRef]

38. Garg, K.; Soslow, R.A. Endometrial carcinoma in women aged 40 years and younger. Arch. Pathol. Lab. Med. 2014, 138, 335-342. [CrossRef]

39. O'Mara, T.A.; Glubb, D.M.; Kho, P.F.; Thompson, D.J.; Spurdle, A.B. Genome-Wide Association Studies of Endometrial Cancer: Latest Developments and Future Directions. Cancer Epidemiol. Biomark. Prev. 2019, 28, 1095-1102. [CrossRef]

40. Chen, Q.; Tong, M.; Guo, F.; Lau, S.; Zhao, M. Parity correlates with the timing of developing endometrial cancer, but not subtype of endometrial cancer. J. Cancer 2015, 6, 1087-1092. [CrossRef]

41. Karageorgi, S.; Hankinson, S.E.; Kraft, P.; De Vivo, I. Reproductive factors and postmenopausal hormone use in relation to endometrial cancer risk in the Nurses' Health Study cohort 1976-2004. Int. J. Cancer 2010, 126, 208-216. [CrossRef] 
42. Dossus, L.; Allen, N.; Kaaks, R.; Bakken, K.; Lund, E.; Tjonneland, A.; Olsen, A.; Overvad, K.; Clavel-Chapelon, F.; Fournier, A.; et al. Reproductive risk factors and endometrial cancer: The European prospective investigation into cancer and nutrition. Int. J. Cancer 2010, 127, 442-451. [CrossRef] [PubMed]

43. Kim, J.-H.; Jong, S.; Park, B.-L.; Sub, H.; Yu, S.J.; Cheong, H.S.; Pasaje, C.F.A.; Bae, J.S.; Lee, H.-S.; Shin, H.D.; et al. TGFBR3 Polymorphisms and Its Haplotypes Associated with Chronic Hepatitis B Virus Infection and Age of Hepatocellular Carcinoma. Dig. Dis. 2011, 744, 278-283. [CrossRef]

44. Charbonneau, B.; Moysich, K.B.; Kalli, K.R.; Oberg, A.L.; Vierkant, R.A.; Fogarty, Z.C.; Block, M.S.; Maurer, M.J.; Goergen, K.M.; Fridley, B.L.; et al. Large-scale evaluation of common variation in regulatory T cell-related genes and ovarian cancer outcome. Cancer Immunol. Res. 2014, 2, 332-340. [CrossRef] [PubMed]

45. Xin, Z.; Zhang, W.; Xu, A.; Zhang, L.; Yan, T.; Li, Z.; Wu, X.; Zhu, X.; Ma, J.; Li, K.; et al. Polymorphisms in the potential functional regions of the TGF- $\beta 1$ and TGF- $\beta$ receptor genes and disease susceptibility in HBV-related hepatocellular carcinoma patients. Mol. Carcinog. 2012, 51, E123-E131. [CrossRef] [PubMed]

46. Chand, A.L.; Robertson, D.M.; Shelling, A.N.; Harrison, C.A. Mutational analysis of betaglycan/TGF- $\beta$ RIII in premature ovarian failure. Fertil. Steril. 2007, 87, 210-212. [CrossRef]

47. Dalgaard, M.D.; Weinhold, N.; Edsgärd, D.; Silver, J.D.; Pers, T.H.; Nielsen, J.E.; Jørgensen, N.; Juul, A.; Gerds, T.A.; Giwercman, A.; et al. A genome-wide association study of men with symptoms of testicular dysgenesis syndrome and its network biology interpretation. J. Med. Genet. 2012, 49, 58-65. [CrossRef]

48. Elliott, L.; Ashley-Koch, A.E.; De Castro, L.; Jonassaint, J.; Price, J.; Ataga, K.I.; Levesque, M.C.; Brice Weinberg, J.; Eckman, J.R.; Orringer, E.P.; et al. Genetic polymorphisms associated with priapism in sickle cell disease. Br. J. Haematol. 2007, 137, 262-267. [CrossRef]

49. Flanagan, J.M.; Frohlich, D.M.; Howard, T.A.; Schultz, W.H.; Driscoll, C.; Nagasubramanian, R.; Mortier, N.A.; Kimble, A.C.; Aygun, B.; Adams, R.J.; et al. Genetic predictors for stroke in children with sickle cell anemia. Blood 2011, 117, 6681-6684. [CrossRef]

50. Hersh, C.P.; Hansel, N.N.; Barnes, K.C.; Lomas, D.A.; Pillai, S.G.; Coxson, H.O.; Mathias, R.A.; Rafaels, N.M.; Wise, R.A.; Connett, J.E.; et al. Transforming growth factor- $\beta$ receptor-3 is associated with pulmonary emphysema. Am. J. Respir. Cell Mol. Biol. 2009, 41, 324-331. [CrossRef]

51. Li, Z.; Allingham, R.R.; Nakano, M.; Jia, L.; Chen, Y.; Ikeda, Y.; Mani, B.; Chen, L.J.; Kee, C.; Garway-Heath, D.F.; et al. A common variant near TGFBR3 is associated with primary open angle glaucoma. Hum. Mol. Genet. 2015, 24, 3880-3892. [CrossRef]

52. Duncan, E.L.; Danoy, P.; Kemp, J.P.; Leo, P.J.; McCloskey, E.; Nicholson, G.C.; Eastell, R.; Prince, R.L.; Eisman, J.A.; Jones, G.; et al. Genome-wide association study using extreme truncate selection identifies novel genes affecting bone mineral density and fracture risk. PLoS Genet. 2011, 7, e1001372. [CrossRef] [PubMed]

53. Khor, C.C.; Ramdas, W.D.; Vithana, E.N.; Cornes, B.K.; Sim, X.; Tay, W.T.; Saw, S.M.; Lavanya, Y.Z.; Wu, R.; Wang, J.J.; et al. Genome-wide association studies in Asians confirm the involvement of ATOH7 and TGFBR3, and further identify CARD10 as a novel locus influencing optic discarea. Hum. Mol. Genet. 2011, 20, 1864-1872. [CrossRef] [PubMed]

54. Xiong, D.H.; Liu, X.G.; Guo, Y.F.; Tan, L.J.; Wang, L.; Sha, B.Y.; Tang, Z.H.; Pan, F.; Yang, T.L.; Chen, X.D.; et al. Genome-wide Association and Follow-Up Replication Studies Identified ADAMTS18 and TGFBR3 as Bone Mass Candidate Genes in Different Ethnic Groups. Am. J. Hum. Genet. 2009, 84, 388-398. [CrossRef] [PubMed]

55. Hanahan, D.; Weinberg, R.A. Hallmarks of cancer: The next generation. Cell 2011, 144, 646-674. [CrossRef] [PubMed]

56. Makker, A.; Goel, M.M. Tumor progression, metastasis, and modulators of epithelial-mesenchymal transition in endometrioid endometrial carcinoma: An update. Endocr. Relat. Cancer 2016, 23, R85-R111. [CrossRef] [PubMed]

57. Zhang, J.; Tian, X.-J.; Xing, J. Signal Transduction Pathways of EMT Induced by TGF- $\beta$, SHH, and WNT and Their Crosstalks. J. Clin. Med. 2016, 5, 41. [CrossRef]

58. Zakrzewski, P.K.; Nowacka-Zawisza, M.; Semczuk, A.; Rechberger, T.; Gałczyński, K.; Krajewska, W.M. Significance of TGFBR3 allelic loss in the deregulation of TGF signaling in primary human endometrial carcinomas. Oncol. Rep. 2016, 35, 932-938. [CrossRef]

(C) 2020 by the authors. Licensee MDPI, Basel, Switzerland. This article is an open access article distributed under the terms and conditions of the Creative Commons Attribution (CC BY) license (http://creativecommons.org/licenses/by/4.0/). 